Nataša Kljajić ${ }^{1}$

Institute of Agricultural Economics Belgrade
ORIGINAL SCIENTIFIC ARTICLE

DOI:10.5937/ekonomika1702045K

Received: March, 21, 2017

Accepted: April, 10, 2017

\title{
PRODUCTION AND EXPORT OF RASPBERRY FROM THE REPUBLIC OF SERBIA ${ }^{2}$
}

\begin{abstract}
Raspberry is the most important and the most profitable export commodity in the structure of agricultural exports. It is exported at an average price of 2.7 USD/ $\mathrm{kg}$, mainly frozen and mostly to the markets of Germany, France and Belgium. Therefore, this paper, in addition to data on raspberry production in Serbia and world raspberry production, also presents the volume and value of frozen raspberry exports from the Republic of Serbia in the period 2010-2015, the dynamics of frozen raspberry exports from Serbia to leading export markets as well as to the frozen raspberry markets of Serbia's main competitors.
\end{abstract}

Keywords: raspberry, production, export, market.

JEL classification: Q10, Q13, P42

\section{ПРОИЗВОДНА И ИЗВОЗ МАЛИНА ИЗ РЕПУБЛИКЕ СРБИЈЕ}

\begin{abstract}
Абстракт
У структури извоза агроиндустријских производа малина представља најзначајнији и најпрофитабилнији извозни производ. Извози се по цени просечно 2,7 УСД/кг и то углавном замрзнута највше у Немачку, Француску и Белгију. Стога је у овом раду, поред података који дају приказ производње малине у нашој земљи и у свету, дат приказ количине и вредности извоза смрзнуте малине из Републике Србије за период 2010-2015. година, динамика извоза смрзнуте малине из Србије на водећим извозним тржиштима, као и извозна тржишта водећих конкурената Србије на тржишту смрзнуте малине.
\end{abstract}

Кључне речи: малина, производюа, извоз, тржиите.

\section{Introduction}

Raspberry is the most profitable fruit species the production of which started in Serbia after World War I (around 1920), and has expanded significantly during recent

\footnotetext{
1 natasa_k@iep.bg.ac.rs

${ }^{2}$ This paper work is result of the project III -46006 Sustainable agriculture and rural development in terms of the Republic of Serbia strategic goals realization within the Danube Region, finance by Ministry of Education, Science and Technological Development of the Republic of Serbia.
} 
years. Factors that contributed to its development and intensification of its production are primarily high yield and long-lasting export to the world market. High economic results achieved in the production process as well as generating profits were crucial in the decision to invest in perennial plantations of raspberries and start economically profitable business. Thus, individual family farms gradually developed into family businesses with a closed production cycle, from raising raspberry plantations to purchasing small cold storage plants for freezing raspberries (dissertation). Most fresh raspberries are sold and consumed during the summer season. The majority of raspberries produced in Serbia are exported frozen (95\%), and only a small amount is exported fresh.

Special economic importance of raspberry production is determined by the following groups of factors:

1. the relatively large value of production, income and profit per unit of invested capital and labour;

2. labour-intensive nature of production, which significantly reduces the problem of unemployment in many areas of the Republic of Serbia;

3. the impact of raspberry production on the overall economic development, which is achieved by building and expanding the capacities of the food industry, by indirect influence on the development of ancillary economic activities, by significant net foreign currency effects, and particularly by investing substantial amounts in infrastructure (particularly construction of local roads) as a basic requirement for the overall social and economic development (Misic et al., 2004).

Intensive raspberry production requires organized approach to improving product quality, increasing the economic efficiency of primary production and processing as well as the active role of the state (providing loans for production of exported commodities under favourable conditions, protection of raspberry as a product of national interest, etc.).

\section{Raspberry production in the Republic of Serbia and world raspberry production}

Raspberry production is concentrated in western and southwestern parts of Serbia in small farms (about 60,000 households) with an average area of 0.25 ha.

There are several regions in Serbia where raspberry production is widespread: 1 . Valjevo region (Podgorina and Pocerina), 2. Sabac region (Nis, Loznica, Bajina Basta), 3. Kosjeric region (Povlen-Varda), 4. Arilje region (Arilje), 5. Ivanjica region (Ivanjica , Kaon, Kotraza, Guca), 6. Cacak region (Cacak and Kablar), 7. Kopaonik region (Brus and its surroundings), 8. Kraljevo region (Kraljevo, Dragacevo), 9. Leskovac region (Leskovac). The greatest part of raspberry production is concentrated in the areas of the following municipalities: Kosjeric, Uzice, Arilje, Pozega, Ivanjica, Valjevo, Mionica, Osecina, Koceljeva, Krupanj, Ljubovija, Gornji Milanovac, Cacak, Lucani, Brus, Aleksandrovac.

Intensive raspberry production has recently begun in almost all parts of our country on smaller areas and due to its profitability in other regions with less optimal conditions for this type of production as well. 
In underdeveloped hilly-mountainous regions a problem that accompanies raspberry production is poor and inadequate infrastructure, while long tradition in raspberry production is its great advantage. However, production of the world's most advanced and highest quality raspberry varieties should be stimulated instead of relying on the old varieties without significant potential. Farm specialization and formation of farmers' associations and organizations is also necessary so that the producers themselves can be more informed about the latest trends in growing raspberries. It is necessary to provide direct assistance to producers through production training seminars.

Another problem in raspberry production is certainly the outflow of labour from rural areas and rising number of elderly households. It is therefore necessary to create conditions for young people to return to the countryside. On the other side, there is enough uneducated and unskilled labour force to perform seasonal jobs, especially in "the rush of harvest". However, as our people lack interest in performing these jobs, labour force is imported from Romania and Bulgaria. In order to improve this situation it is necessary to comply with the regulations of the EU, especially in terms of hygiene and respect for human rights during the harvest, and also in terms of education and professional training of workers.

Raspberry production is an exceptional opportunity for development of agriculture and overall economy of Serbia. It can be accomplished by increasing the economic efficiency of both primary production and processing and improvement of product quality.

Important factors to achieve good economy are the large flexibility of the producers, and many advantages of such a fragmented production as:

- Low-cost investments without many inputs: only the planting material and plant support system.

- Developed necessary infrastructure of roads, cold storages, market places, etc.

- Quick return on investment - but, from the second year.

- Involvement of unemployed family members in crop maintenance and harvest. In this way growers can provide a cheaper product and gain higher incomes.

- Easier managing that reduces the economic impact of low prices and hard sale conditions. Small producers tolerate easier the reduction in yield or no yield of some years (Nikolić and Tanović, 2012).

According to the 2012 Census of Agriculture, the orchards in the Republic of Serbia occupy a total of 295,203 ha. Plantation orchards occupy an area of 98,575 ha and extensive orchards occupy 64,736 ha (Table 1).

Table 1. The surface area and structure of orchards according to the 2012 Census of Agriculture

\begin{tabular}{|l|c|c|c|c|}
\hline & \multirow{2}{*}{$\begin{array}{c}\text { Agricultural } \\
\text { holdings,number }\end{array}$} & total & plantation & extensive \\
\cline { 3 - 5 } & 295.203 & 163.310 & 98.575 & 64.736 \\
\hline Republic of Serbia & & &
\end{tabular}

Source: Census of Agriculture 2012, Book I 
According to the same data source raspberry plantations in our country occupy an area of 11.041 ha. The most widely spread are plums ( 77,949 ha), followed by cherries ( $13,990 \mathrm{ha})$ and apples ( $23,737 \mathrm{ha})$. They are followed by peaches ( $8,012 \mathrm{ha})$, pears (7,343 ha), nuts( 4,787 ha), etc.

Raspberry production in Serbia in the period 2006-2015 is shown in Table 2. It reveals that the average production in this period was $76,807 \mathrm{t}$ with an average yield of $5.7 \mathrm{t} /$ ha generated on an average area of 13,579 ha.

Table 2.Raspberry production in Serbia in the period 2006-2015

\begin{tabular}{|c|c|c|c|}
\hline \multirow[b]{2}{*}{ Year } & \multicolumn{3}{|c|}{ Republic of Serbia } \\
\hline & Area under raspberries (ha) & $\begin{array}{c}\text { Total yield } \\
\text { (t) }\end{array}$ & $\begin{array}{l}\text { Yield } \\
\text { (t/ha) }\end{array}$ \\
\hline 2006 & 15.024 & 79.680 & 5,3 \\
\hline 2007 & 14.496 & 76.991 & 5,3 \\
\hline 2008 & 14.680 & 84.299 & 5,7 \\
\hline 2009 & 14.957 & 86.961 & 5,8 \\
\hline 2010 & 15.174 & 83.870 & 5,5 \\
\hline 2011 & 15.354 & 89.602 & 5,8 \\
\hline 2012 & 11.996 & 70.320 & 5,9 \\
\hline 2013 & 12.024 & 68.458 & 5,7 \\
\hline 2014 & 11.040 & 61.715 & 5,6 \\
\hline 2015 & 11.041 & 66.176 & 6,0 \\
\hline Average & $13.578,6$ & $76.807,2$ & 5,7 \\
\hline
\end{tabular}

Source: Statistical Office of the Republic of Serbia, Statistical Yearbook of the Republic of Serbia, 2007-2016

Furthermore, according to the FAO, Serbia is among the world's leading raspberry producers. In the research period 2010-2014, Serbia ranked 4th in raspberry production. Among the world's leading raspberry producers, only the USA achieved higher yields than Serbia (all years observed) and the Russian Federation in 2013 and 2014 (Table 3).

Table 3. Top five producers of raspberries in the world in the period 2010-2014/

\begin{tabular}{|c|c|c|c|c|c|c|}
\hline \multirow{2}{*}{\multicolumn{2}{|c|}{$\begin{array}{c}\text { Research year, } \\
\text { raspberry production } \\
\text { and yield }\end{array}$}} & \multicolumn{5}{|c|}{ Countries } \\
\hline & & \multirow{2}{*}{$\begin{array}{r}\begin{array}{c}\text { Russian } \\
\text { Federation }\end{array} \\
125.000\end{array}$} & \multirow{2}{*}{$\begin{array}{r}\text { Poland } \\
92.864 \\
\end{array}$} & \multirow{2}{*}{$\begin{array}{l}\text { USA } \\
88.020\end{array}$} & \multirow{2}{*}{$\begin{array}{r}\begin{array}{c}\text { Republic of } \\
\text { Serbia }\end{array} \\
\mathbf{8 3 . 8 7 0} \\
\end{array}$} & \multirow{2}{*}{$\begin{array}{r}\text { Ukraine } \\
25.700 \\
\end{array}$} \\
\hline & Production $(\mathrm{t})$ & & & & & \\
\hline 2010 & Yield (t/ha) & 4,8 & 3,1 & 8,7 & 5,5 & 5,0 \\
\hline \multirow{2}{*}{2011} & Production $(\mathrm{t})$ & 140.000 & 117.995 & 109.502 & 89.602 & 28.100 \\
\hline & Yield (t/ha) & 4,9 & 4,4 & 10,9 & 5,8 & 5,5 \\
\hline \multirow{2}{*}{2012} & Production $(\mathrm{t})$ & 133.000 & 127.055 & 84.300 & 70.320 & 30.300 \\
\hline & Yield (t/ha) & 5,1 & 4,5 & 12,0 & 5,9 & 6,1 \\
\hline \multirow{2}{*}{2013} & Production $(\mathrm{t})$ & 143.000 & 121.040 & 83.280 & 68.458 & 30.411 \\
\hline & Yield (t/ha) & 8,9 & 4,2 & 11,1 & 5,7 & 15,5 \\
\hline \multirow{2}{*}{2014} & Production $(\mathrm{t})$ & 144.000 & 125.859 & 103.510 & 61.715 & 35.627 \\
\hline & Yield (t/ha) & 8,7 & 4,5 & 13,1 & 5,6 & 15,2 \\
\hline
\end{tabular}

Source: FAOSTAT, http://www.fao.org/faostat/en/\#data.

${ }^{1}$ The list of countries should be supplemented by Chile. According to FAO data, the 
average raspberry production in Chile in the period 2010-2014 was only 3,120 tons, and according to International Raspberry Organization - IRO, the average raspberry production in Chile was around 50,981 tons in the period 2009-2013

\section{The volume and value of frozen raspberry exports from the Republic of Serbia}

The key indicator of the development of agriculture and food industry of a country is the export of agricultural products. Therefore, export is of great importance from the point of view of the national economy. A large number of factors influence the placement of agricultural products in the international market, of which the most important are: price, quality, competitiveness, certain administrative measures of state bodies, etc.

In the period January-August 2016, Serbia exported 2 billion USD worth of agricultural products. This export level is by $7.1 \%$ higher than in the same period of the previous year. The most important export products were: maize worth 207 million, cigarettes worth 199 million, frozen raspberries worth 172 million, and wheat worth 101 million. When considering export by commodity group, the best result is achieved by fruit and vegetables with export worth 547 million USD, accounting for $5.6 \%$ of the total exports of commodities. Wheat and grain- based products were exported for 450 million USD, accounting for $4.6 \%$ of the total exports of commodities.(Agribusiness - sectoral overview September 2016, Serbian Chamber of Commerce).

Serbia is the world's leading country in terms of the value of frozen raspberry exports. To find a place in the global market where competition is ever more present and more brutal, one needs to focus on quality, professionalism, price, etc. Export prospects are great because raspberries from Serbia are, among other things, considered a "healthysafe food" as well. Export demand for Serbian raspberries is significant and stable.

In the period 2011-2015, the average value of exports from the Republic of Serbia amounted to 241,756 USD. Average volume of frozen raspberry exports amounted to 96,399 tons and the average unit value of exports amounted to $2.5 \mathrm{USD} / \mathrm{kg}$ (Table 4).

Table 4. Leading exporters of frozen raspberry in the world by value of exports in the period 2011-2015

\begin{tabular}{|c|l|r|r|r|}
\hline Rank & \multicolumn{1}{|c|}{ Countries } & \multicolumn{1}{|c|}{$\begin{array}{c}\text { Average value of } \\
\text { exports, } \\
\text { (thousands of USD) }\end{array}$} & $\begin{array}{c}\text { Average volume of } \\
\text { exports (ton) }\end{array}$ & $\begin{array}{c}\text { Average unit value } \\
\text { of exports } \\
\text { (USD/kg) }\end{array}$ \\
\hline $\mathbf{1 .}$ & $\begin{array}{l}\text { Republic of } \\
\text { Serbia }\end{array}$ & $\mathbf{2 4 1 . 7 5 6}$ & $\mathbf{9 6 . 3 9 9}$ & $\mathbf{2 , 5}$ \\
\hline 2. & Poland & 171.721 & 101.725 & 1,7 \\
\hline 3. & Chile & 168.394 & 56.320 & 3,0 \\
\hline
\end{tabular}

1 Product code: 081120 - includes frozen raspberries, blackberries, mulberries, loganberries, currants and gooseberries.

Source: International Trade Centre (ITC), Trade Map, http://www.trademap.org/Index.aspx.

In terms of value and volume of frozen raspberry exports, Serbia's main competitors in this market are Poland and Chile. Average export volume of frozen raspberries from Poland is 101,725 tons and 56,320 tons from Chile. 
In terms of the value of exports, frozen raspberry was among the top 10 Serbian export products in the period 2010-2015 (Table 5). Export ranking of frozen raspberries increased over time, so that in 2015 this product was in 6th place regarding the value of exports.

Table 5. Serbian frozen raspberry exports (with no sugar added) in the period 2010-2015

\begin{tabular}{|c|c|r|r|r|}
\hline Year & $\begin{array}{c}\text { Ranking of frozen } \\
\text { raspberries among the } \\
\text { top 10 Serbian export } \\
\text { products }\end{array}$ & $\begin{array}{c}\text { Exports, } \\
\text { volume (t) }\end{array}$ & $\begin{array}{c}\text { Exports, value } \\
\text { (000 USD) }\end{array}$ & $\begin{array}{c}\text { Unit value of } \\
\text { exports (USD/ } \\
\mathrm{kg} \text { ) }\end{array}$ \\
\hline 2010 & 7 & $61.494,2$ & $165.578,2$ & 2,7 \\
\hline 2011 & 7 & $73.547,8$ & $176.471,4$ & 2,4 \\
\hline 2012 & 10 & $64.268,1$ & $135.648,1$ & 3,1 \\
\hline 2013 & 10 & $61.416,9$ & $187.357,7$ & 3,2 \\
\hline 2014 & 8 & $73.252,6$ & $236.517,6$ & 2,9 \\
\hline 2015 & 6 & 93.713 .6 & $267.945,4$ & \\
\hline
\end{tabular}

Source: Statistical Office of the Republic of Serbia http://webrzs.stat.gov.rs/WebSite/ public/ReportView.aspx.

The average export price of frozen raspberries was $2.7 €$ per $\mathrm{kg}$, and it depends on the quality, produced and offered quantities, logistics, drying and packaging.

The price of labour in raspberry production in our country is about five times lower than in the EU countries. Unlike the countries of the European Union where raspberries are grown with the use of advanced technical and technological practices, in our country raspberries are cultivated manually. Purchase price or sales price of raspberries is a constant cause of conflict between producers and purchasers who are actually the owners of cold storage plants for freezing fresh fruit. The solution to these problems would greatly contribute to greater income in foreign exchange for all participants in the production chain.

Frozen raspberries from Serbia are predominantly exported to the markets of: Germany, France, Belgium (Table 6). The dynamics of frozen raspberries exports from Serbia into leading export markets in the period 2011-2015 is shown. Exports to Germany increased in this period and amounted to 98.570 USD in 2015. The value of frozen raspberries exports to France was also the highest in 2015 (61,562 USD), while the exports to Belgium showed no major oscillations in this period. Countries of the EU which are deficient in raspberry and have a relatively high living standard, characterize raspberry as a healthy-safe food. Therefore, its exports are promising and can significantly increase with appropriate marketing measures.

Table 6. The dynamics of frozen raspberry exports from Serbia into leading export markets in the period 2011-2015

- value of exports in thousands of USD -

\begin{tabular}{|l|r|r|r|r|r|}
\hline & \multicolumn{1}{|c|}{$\mathbf{2 0 1 1}$} & $\mathbf{2 0 1 2}$ & \multicolumn{1}{c|}{$\mathbf{2 0 1 3}$} & \multicolumn{1}{c|}{$\mathbf{2 0 1 4}$} & \multicolumn{1}{c|}{$\mathbf{2 0 1 5}$} \\
\hline 1.Germany & $\mathbf{7 5 . 0 0 3}$ & 63.501 & 80.164 & 90.600 & 98.570 \\
\hline 2.France & 40.874 & 35.315 & 47.011 & 56.779 & 61.562 \\
\hline 3.Belgium & 23.782 & 23.251 & 29.913 & 29.310 & 29.622 \\
\hline
\end{tabular}


I'Product code: 081120 - includes frozen raspberries, blackberries, mulberries, loganberries, currants and gooseberries.

Source: International Trade Centre (ITC), Trade Map, http://www.trademap.org/Index.aspx.

If we look at 2011 as the base year for analysis and 2015 is the comparison year, we can notice that the value of frozen raspberry exports from Serbia increased: into the German market by $31.42 \%$, into the French market by $50.61 \%$ and into the Belgian market by $24.56 \%$.

As indicated above, Chile and Poland are Serbia's strongest competitors in frozen raspberry market. The following table (Table 7) presents frozen raspberry markets of Serbia's strongest competitors.

Table 7. Export markets of Serbia's leading competitors in the frozen raspberry market - value of exports in thousands of USD -

\begin{tabular}{|l|r|r|r|r|r|}
\hline & 2011 & 2012 & 2013 & 2014 & 2015 \\
\hline \multicolumn{7}{|c|}{ Poland } \\
\hline 1.Germany & 48.054 & 50.069 & 63.660 & 61.150 & 60.764 \\
\hline 2.Belgium & 16.390 & 14.810 & 27.025 & 25.727 & 22.011 \\
\hline 3.Holland & 11.744 & 9.683 & 14.629 & 16.043 & 13.394 \\
\hline 4.Great Britain & 9.790 & 11.485 & 14.422 & 15.595 & 12.959 \\
\hline 5.France & 9.101 & 9.467 & 12.185 & 15.544 & 11.921 \\
\hline \multicolumn{7}{|c|}{ Chile } \\
\hline 1.USA & 60.810 & 52.962 & 64.881 & 87.042 & 81.859 \\
\hline 2.Canada & 19.077 & 17.731 & 26.496 & 24.524 & 30.663 \\
\hline 3.Australia & 10.483 & 8.387 & 11.478 & 13.739 & 11.699 \\
\hline 4.France & 13.027 & 13.235 & 14.361 & 8.602 & 10.770 \\
\hline 5.Holland & 14.367 & 7.437 & 12.119 & 10.205 & 9.108 \\
\hline
\end{tabular}

/1 Product code: 081120 - includes frozen raspberries, blackberries, mulberries, loganberries, currants and gooseberries.

Source: International Trade Centre (ITC), Trade Map, http://www.trademap.org/Index.aspx.

With regard to the orientation of frozen raspberry exports, Serbia's main competitor is Poland, considering the fact that its export markets are largely compatible with Serbia's export markets.

\section{Conclusion}

Serbia has the potential to produce, process and develop high-quality assortment of agricultural products and to increase exports of agricultural and food products into the European and world market. Favourable agroecological natural resources and potentials for agricultural production are not used sufficiently, which is reflected in yields lower than potential yields, and compared to the countries of the European Union.

Raspberry is our most important export product in the field of agro-industrial products. In previous research period, our country has achieved significant results in raspberry exports into the international market. A significant trend in increasing exports 
is encouraging. Raspberry is mostly exported to Germany, Belgium and France, and Serbia's strongest competitors are Poland and Chile.

In order to strengthen the already acquired position and simultaneously win new export markets for raspberries, it is necessary to define general policy, to examine perspectives and to establish long-term programs for raspberry production and processed raspberry production in accordance with the requirements and demand of the European and world market. The support of the Ministry of Agriculture is necessary in joint planning with raspberry producers regarding the purchase price of fresh raspberries in the following period, as well as assistance through subsidies and loans in the production process.

\section{References}

Cecić N., Milivojević J., Arsić S., (2006a): Ekonomičnost ulaganja u sistem za navodnjavanje u klimatskim uslovima ariljskog malinogorja. Naučni skup sa međunarodnim učešćem „Perspektive agrobiznisa Srbije i evropske integracije“, Valjevo. Ekonomika poljoprivrede, br. 3, Beograd, str. 809-821.

Cecić N., Subić J., Vuković P. (2007): Proizvodnja maline u funkciji ruralnog razvoja. Međunarodni naučni skup: Multifunkcionalna poljoprivreda i ruralni razvoj u Republici Srpskoj “. Tematski zbornik. Jahorina, 13.-14. decembar 2007. godine, str. 379-386.

Nikolić M., Tanović B. (2012): Rubus and ribes industry in Serbia: a production model for developing countries. ActaHorticulturae 946, X International Rubus and Ribes Symposium, pp. 405-412.

Kljajić N., Vuković P., Arsić S., (2013): Tendencije proizvodnje maline u Republici Srbiji. Ekonomika poljoprivrede, 60(1), str. 39-48.

Kljajić N., (2013): Efikasnost investicija u proizvodnji maline. Institut za ekonomiku poljoprivrede, Beograd.

Kljajić, N., Grujić, B., \& Roljević, S. (2013). Voćarska proizvodnja Gornjeg Podunavlja prema obliku svojine. Ekonomika, 59(3), 57-64., str. 57-64

Kljajić, N., \& Vuković, P. (2014). Fruit Production Analysis in Republic of Serbia in the Function of Rural Development. Sustainable agriculture and rural development in terms of the republic of Serbia strategic goals realization within the Danube region. Rural development and (un) limited resources, 444-460.

Kljajić N., (2016): Analysis of conditions and results of the raspberry production in Arilje raspberry-mount. Sustainable agriculture and rural development in terms of the Republic serbia strategic goals realization within the Danube regiondevelopment and application of clean technologies in agriculture- Thematic proceedings. Institute of Agricultural Economics Belgrade. pp. 2016-233.

Mišić P., Tešović Ž., Stanisavljević M., Milutinović M., Nikolić M., Milenković S. (2004): Malina u Srbiji i Crnoj Gori-prošlost, sadašnjost i budućnost. Jugoslovensko voćarstvo, 38(145-146), str. 5-22.

Milivojević J., Bošnjaković G., Zloh Z., Denić M., Cecić N., Matović G. (2000): Pilot sistem za navodnjavanje Ariljskog malinogorja "Rubus-Arilje", područje sela: Dragojevac, Mirosaljci, Trešnjevica, Stupčevići, Latvica, Bogojevići ( $\mathrm{P}=5.732$ ha). Razvojni program. Poljoprivredni fakultet. Beograd, str. 1-75. 
Milić D., Galić D., Vukoje V. (2011): Mogućnosti unapređenja voćarske proizvodnje u Srbiji. Journal of Processing and Energy in Agriculture, 15(1), pp. 27-30.

Nikolić, M., Ivanović, M., Milenković, S., Milivojević Jasminka, Milutinović, M., (2008): The State and Prospects of Raspberry Production in Serbia. ISHS Acta Horticulturae 777: IX International Rubus and Ribes Symposium. Pucón, Chile, number of article 83, Vol. 1.

Simonović Z., (2014): Upravljanje agrarom Srbije u tranziciji, Institut za ekonomiku poljoprivrede, Beograd.

Sredojević, Z., Kljajić, N., \& Popović, N. (2013). Investing in Raspberry Production as an Opportunity of Sustainable Development of Rural Areas in Western Serbia. Economic Insights-Trends and Challenges, 1, 63-72.

Republički zavod za statistiku, Popis poljoprivrede, 2012. god., Knjiga I

Republički zavod za statistiku, Statistički godišnjak Republike Srbije, 2007-2016.

Agrobiznis-sektorski pregled septembar 2016. godine_Privredna komora Srbijehttp:// www.pks.rs/SADRZAJ/Files/AGROBIZNIS-CEVES-PKS-decembar\%20 2016\%20srp.pdf (pristup na dan 21.01.2017)

FAOSTAT, http://www.fao.org/faostat/en/\#data (pristup na dan 15.02.2017)

International Trade Centre (ITC), Trade Map, http://www.trademap.org/Index.aspx (pristup na dan 15.02.2017.) 